\begin{tabular}{|c|c|}
\hline \multirow{3}{*}{ 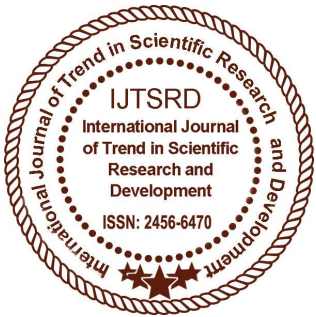 } & $\begin{array}{l}\text { International Journal of Trend in Scientific } \\
\text { Research and Development (IJTSRD) }\end{array}$ \\
\hline & International Open Access Journal \\
\hline & ISSN No: 2456 - 6470 | www.ijtsrd.com | Volume - 2 | Issue - 1 \\
\hline
\end{tabular}

\title{
Estimation of Bioactive Compound of Catharanthus roseus Leaf extract by Phytochemical Screening and GC-MS Analysis
}

\author{
S. Nathiya ${ }^{1}$, N. Shaishta Jabeen ${ }^{1}$, L. Jagapriya ${ }^{1}$, B. Senthilkumar ${ }^{2}$, K. Devi ${ }^{{ }^{*}}$ \\ ${ }^{\mathbf{1}}$ Department of Zoology, D. K. M. College for Women, Vellore, Tamil Nadu, India \\ ${ }^{2}$ Department of Zoology, Thiruvalluvar University, Serkadu, Vellore, Tamil Nadu, India
}

\begin{abstract}
Plant derived compounds have played a vital role in the development of several chemotherapeutic agents. Catharanthus roseus is an important medicinal plant of the apocynaceae family. The leaf extract of Catharanthus roseus have many biological activities such as antibacterial, antioxidant and antidiabetes. The present study was aimed to carry out the phytochemical analysis and the GC-MS analyses of Cathranthus roseus leaf extract ensure biological activity in the presence bioactive compounds. The leaves designated to the presence of secondary metabolites (proteins, steroids, tannins,glycosides, reducing sugar, carbohydrates,saponins, sterols, terpenoids, acidic compounds, cardiac glycosides, phenols, alkaloids,flavonoids). In the GC-MS analysis the Cathranthus roseus extract result shows the presence of bioactive compounds which revealed a broad spectrum of many medicinal property and antioxidant activity were identified. This study is helped to identify bioactive compound formula and structure which can be used as pharmaceutical industries for drug discovery.
\end{abstract}

Keywords: Catharanthus roseus, antibacterial, antioxidant antidiabetes

\section{INTRODUCTION}

Medicinal plants are the oldest form of healthcare known to mankind. From the ancient time people are using different types of plants as the remedy for

various diseases. According to World Health Organization (WHO) approximately $80 \%$ of the World's population the herbal medicine was used to treat them traditionally (Mayuri Thanwar et al).

Medicinal plants have vast and diverse assortment of bioactive compounds, than can produce a definite physiological action on the human body. These bioactive compounds have been isolated from plants which could be used for the development of new drugs; pharmacists are interested in these compounds because of their therapeutic performance and low toxicity.

Catharanthus roseus is an important medicinal plant family apocyanaceae also known as Vincarosea Indian originated herb. Catharanthus roseus as used as medicine for traditionally treating many diseases they are Malaria, Diabetes, Leukemia, Wasp sting, Sore throat, Eye irritation, Astringent, Diuretic and Expectorant (S. Patharajan et al). The plant also possesses various medicinal properties such as antimicrobial, antioxidant, antihelmintic antifeedant, antiserility, antidiarrheal, antidiabetic (Gajalakshmi et al). These Properties of Catharanthus roseus due to the presence of biologically active compounds of biological importance. In this study carried out identify the phytocompounds in the ethanolic leaf extract of Cathranthus roseus by qualitative screening of phytochemicals and each compound with their concentration by Gas Chromatography - Mass Spectrum (GC-MS) analysis. 


\section{Materials and Methods}

\section{Collection of plant material}

Catharanthus roseus leaves were collected from Vellore District. The leaves were washed with water to remove soil and dust particles, and then it was dried under shady place. The dried plant material were blended to form a fine powder and stored in airtight bottles.

\section{Extract preparation}

Plant material were used for the solvent extraction procedure, about $10 \mathrm{gm}$ of plant powder was soaked in $100 \mathrm{ml}$ of ethanol for 48 hours. The contents were then filtered through Whatsman filter paper no.1. The crude extract was subjected Gas Chromatography and Mass Spectrum to find the Bioactive compounds present in plant extract.

Phytochemical analysis standard procedure $(9,10$, 11)

The extract of Catharanthus roseus tested for the bioactive compounds by using following methods

\section{Test for Proteins}

\section{Millon's test}

Crude extract when mixed with $2 \mathrm{ml}$ of Millon's reagent, white precipitate appeared which turned red upon gentle heating that confirmed the presence of protein.

\section{Ninhydrin test}

Crude extract when boiled with $2 \mathrm{ml}$ of $0.2 \%$ solution of Ninhydrin, violet colour appeared suggesting the presence of amino acids and proteins.

\section{Test for carbohydrates}

\section{Fehling'stest}

Equal volume of Fehling $\mathrm{A}$ and Fehling $\mathrm{B}$ reagents were mixed together and $2 \mathrm{ml}$ of it was added to crude extract and gently boiled. A brick red precipitate appeared at the bottom of the test tube indicated the presence of reducing sugars.

\section{Benedict's test}

Crude extract when mixed with $2 \mathrm{ml}$ of Benedict's reagent and boiled, a reddish brown precipitate formed which indicated the presence of the carbohydrates.

\section{Molisch's test}

Crude extract was mixed with $2 \mathrm{ml}$ of Molisch's reagent and the mixture was shaken properly. After that, $2 \mathrm{ml}$ of concentrated $\mathrm{H} 2 \mathrm{SO} 4$ was poured carefully along the side of the test tube. Appearance of a violet ring at the interphase indicated the presence of carbohydrare.

\section{Iodine test}

Crude extract was mixed with $2 \mathrm{ml}$ of iodine solution. A dark blue or purple coloration indicated the presence of the carbohydrate.

\section{Test for phenols and tannins}

Crude extract was mixed with $2 \mathrm{ml}$ of $2 \%$ solution of $\mathrm{FeCl} 3$. A blue-green or black coloration indicated the presence of phenols and tannins.

\section{Test for flavonoids}

\section{Shinoda test}

Crude extract was mixed with few fragments of magnesium ribbon and concentrated $\mathrm{HCl}$ was added drop wise. Pink scarlet colour appeared after few minutes which indicated the presence of flavonoids.

\section{Alkaline reagent test}

Crude extract was mixed with $2 \mathrm{ml}$ of $2 \%$ solution of $\mathrm{NaOH}$. An intense yellow colour was formed which turned colourless on addition of few drops of diluted acid which indicated the presence of flavonoids.

\section{Test for Saponins}

Crude extract was mixed with $5 \mathrm{ml}$ of distilled water in a test tube and it was shaken vigorously. The formation of stable foam was taken as an indication for the presence of saponins.

\section{Test for glycosides Libermann's test}

Crude extract was mixed with each of $2 \mathrm{ml}$ of chloroform and $2 \mathrm{ml}$ of acetic acid. The mixture was cooled in ice. Carefully concentrated H2SO4 was added. A colour change from violet to blue to green indicated the presence of steroidal nucleus, i.e., glycone portion of glycoside.

\section{Salkowski's test}


Crude extract was mixed with $2 \mathrm{ml}$ of chloroform. Then $2 \mathrm{ml}$ of concentrated $\mathrm{H} 2 \mathrm{SO} 4$ was added carefully and shaken gently. A reddish brown colour indicated the presence of steroidal ring, i.e., glycone portion of the glycoside.

\section{Keller-kilani test}

Crude extract was mixed with $2 \mathrm{ml}$ of glacial acetic acid containing 1-2 drops of $2 \%$ solution of $\mathrm{FeCl} 3$. The mixture was then poured into another test tube containing $2 \mathrm{ml}$ of concentrated $\mathrm{H} 2 \mathrm{SO} 4$. A brown ring at the interphase indicated the presence of cardiac glycosides.

\section{Test for steroid}

Crude extract was mixed with $2 \mathrm{ml}$ of chloroform and concentrated $\mathrm{H} 2 \mathrm{SO} 4$ was added sidewise. A red colour produced in the lower chloroform layer indicated the presence of steroids. Another test was performed by mixing crude extract with $2 \mathrm{ml}$ of chloroform. Then $2 \mathrm{ml}$ of each of concentrated H2SO4 and acetic acid were poured into the mixture. The development of a greenish coloration indicated the presence of steroids.

\section{Test for terpenoids}

Crude extract was dissolved in $2 \mathrm{ml}$ of chloroform and evaporated to dryness. To this, $2 \mathrm{ml}$ of concentrated $\mathrm{H} 2 \mathrm{SO} 4$ was added and heated for about 2 minutes. A grayish colour indicated the presence of terpenoids.

\section{Test for alkaloids}

Crude extract was mixed with $2 \mathrm{ml}$ of $1 \% \mathrm{HCl}$ and heated gently. Mayer's And Wagner's reagents were then added to the mixture. Turbidity of the resulting precipitate was taken as evidence for the presence of alkaloids.

\section{GC-MS analysis}

The GC-MS anlaysis of ethanol extract Cathranthus roseus was performed using a Clarus $680 \mathrm{GC}$ was used in the analysis employed a fused silica column, packed with Elite-5MS $(5 \%$ biphenyl $95 \%$ dimethylpolysiloxane, $30 \mathrm{~m} \times 0.25 \mathrm{~mm}$ ID $\times 250 \mu \mathrm{m}$ df) and the components were separated using Helium as carrier gas at a constant flow of $1 \mathrm{ml} / \mathrm{min}$. The injector temperature was set at $260^{\circ} \mathrm{C}$ during the chromatographic run. The $1 \mu \mathrm{L}$ of extract sample injected into the instrument the oven temperature was as follows: $60{ }^{\circ} \mathrm{C}(2 \mathrm{~min})$; followed by $300{ }^{\circ} \mathrm{C}$ at the rate of $10{ }^{\circ} \mathrm{C}$ min-1; and $300{ }^{\circ} \mathrm{C}$, where it was held for $6 \mathrm{~min}$. The mass detector conditions were: transfer line temperature $240{ }^{\circ} \mathrm{C}$; ion source temperature $240{ }^{\circ} \mathrm{C}$; and ionization mode electron impact at $70 \mathrm{eV}$, a scan time $0.2 \mathrm{sec}$ and scan interval of $0.1 \mathrm{sec}$. The fragments from 40 to $600 \mathrm{Da}$. The spectrums of the components were compared with the database of spectrum of known components stored in the GC-MS NIST (2008) library.

\section{Result}

The Phytochemical screening of Cathranthus roseus qualitatively analyzed in our lab by the standard methods exhausting identified the secondary metabolites of flavonoids, glycosides, tannins, terpenoids, phenol, steroids, alkaloids and carbohydrates were found in the ethanol leaf extract of this plant and the result are presented in Table 1.

The GC-MS analysis revealed the presence of 12 compounds from the ethanol extract of Catharanthus roseus active principles with their retention time (RT), molecular formula, molecular weight (MW), and concentration (peak area \%) are presented in Table 2. The compunds are identified by the mass spectroscopy were presented. The total numbers of compounds identified in the ethanol extract were 1Octadecyne (43.66\%) and Tridecanoic acid (20.02\%) was found as the 2 major components and other 10 minor compounds such as Hexatriacontane (1.92\%), 1,2-Bis(Trimethylsilyl)Benzene (2.963), DI-NDecylsulfone (2.09\%), UnDecanoic acid (2.24\%), N-Hexadecanoic acid (2.34\%), Hexatriacontane (3.76\%), 4-Heptanol, 2-Methyl (4.68\%), Sqalene (4.34\%), Heotacosane (5.41\%), 2h-1-Benzopyran-6Ol, 3,4-Dihydro-2,5,7,8-Tetramethyl-2-(4,8,12Trimethyltridecyl)-, Acetate (6.54\%). These peak values represents phytocomponents are present in the ethanol extract of Catharanthus roseus leaves.

\section{Discussion}

In this study, the preliminary phytochemical screening as shown Table 1. Revealed the presence of alkaloids, flavonoids, saponins, tannins, terpenoids, glycosides, phenols, carbohydrates, protein and amino acids. This Secondary metabolite of the ethanol extract of Cathranthus roseus leaves retain medicinal importance. The presence of alkaloids and phenol compounds of Secondary metabolites responsible for pharmacological activities like anti-cancer, antioxidant, anti-microbial, antifertility, wound healing 
and anti-inflammatory, that may well this plant proving to vast valuable bioactive compounds are possess medicinal value. The GC-MS analysis to showed 12 compounds are present in the ethanol extract of Cathranthus roseus fragmentation pattern of N-Hexadecanoic acid have a Antioxidant, Antimicrobial , Antiinflammatory, properties, 4heptanol, 2-methyl compound effective for Antioxidant, and 2h-1-Benzopyran-6-Ol, 3,4Dihydro-2,5,7,8-Tetramethyl-2-(4,8,12-Trimethy compound involved in Antioxidant, Antimicrobial activity. The source of many medicinal plants has phytochemical compounds identified from the peak pattern of the chromatograms obtained directly from GC-MS analysis. Similarly, The GC-MS analysis will show the bioactive compound present in the ethanol extract of Catharanthus roseus have many biological properties that can be used in treat to cure many diseases. In this study carried out identify the phytocompounds in the ethanolic leaf extract of Catharanthus roseus by qualitative screening of phytochemicals and each compound with their concentration by Gas Chromatography - Mass Spectrum (GC-MS) analysis were used in medicinal uses.

\section{Conclusion}

The ethanol leaf extract of Catharanthus roseus contain many phytochemical components The GCMS analysis showed the presence of bioactive compounds in the leaves further studies are needed to detect the various other solvents of methanol, petroleum ether, chloroform and aqueous.

Table: 1 Phytochemical Constituents analysis of ethanol extract of Catharanthus roseus

\begin{tabular}{|l|l|l|}
\hline S. No. & Name of the Test & $\begin{array}{l}\text { Phytochemical analysis of } \\
\text { Catharanthus roseus }\end{array}$ \\
\hline 1. & Test for protein Ninhydrin test & + \\
\hline 2. & $\begin{array}{l}\text { Test for Carbohydrate } \\
\text { Molisch's test, Iodeine test }\end{array}$ & + \\
\hline 3. & Test for phenols and tannins & ++ \\
\hline 4. & $\begin{array}{l}\text { Test for flavonoids } \\
\text { Alkalinereagent test }\end{array}$ & + \\
\hline 5. & Test for Saponins glycosides & + \\
\hline 6. & $\begin{array}{l}\text { Test for } \\
\text { Salkowski's test }\end{array}$ & + \\
\hline 7. & Test for steroid & + \\
\hline 8. & Test for terpenoids & + \\
\hline 9. & Test for alkaloids & + \\
\hline
\end{tabular}


International Journal of Trend in Scientific Research and Development (IJTSRD) ISSN: 2456-6470

Table: 2 Phytocomponents identified in the ethanol leaf extract of Catharanthus roseus by GC-MS analysis

\begin{tabular}{|c|c|c|c|c|c|c|}
\hline $\begin{array}{l}\text { S. } \\
\text { No. }\end{array}$ & $\mathbf{R t}$ & $\begin{array}{l}\text { Peak } \\
\text { Value }\end{array}$ & Cmpound Name & $\begin{array}{l}\text { Molecular } \\
\text { Weight }\end{array}$ & $\begin{array}{l}\text { Molecular } \\
\text { Formula }\end{array}$ & Bioactivity \\
\hline 1. & 17.199 & 2.342 & N-Hexadecanoic acid & 256 & $\mathrm{C}_{16} \mathrm{H}_{32} \mathrm{O}_{2}$ & $\begin{array}{l}\text { Antioxidant, Antimicrobial, } \\
\text { Antiinflammatory }\end{array}$ \\
\hline 2. & 18.965 & 4.683 & 4-heptanol, 2-methyl & 130 & $\mathrm{C}_{8} \mathrm{H}_{18} \mathrm{O}$ & Antioxidant \\
\hline 3. & 19.84 & 20.023 & Tridecanoic acid & 214 & $\mathrm{C}_{13} \mathrm{H}_{26} \mathrm{O}_{2}$ & No activity found \\
\hline 4. & 20.431 & 2.24 & Undecanoic acid & 186 & $\mathrm{C}_{11} \mathrm{H}_{22} \mathrm{O}_{2}$ & No activity found \\
\hline 5 . & 21.146 & 43.66 & 1-Octadecyne & 250 & $\mathrm{C}_{18} \mathrm{H}_{36} \mathrm{O}_{2}$ & No activity found \\
\hline 6. & 24.497 & 3.762 & Hexatriacontane & 506 & & No activity found \\
\hline 7. & 25.318 & 4.349 & Squalene & 410 & $\mathrm{C}_{30} \mathrm{H}_{50}$ & $\begin{array}{l}\text { Antioxidant, chemopreventive, } \\
\text { antitumour and } \\
\text { Hypocholesterolemic }\end{array}$ \\
\hline 8. & 25.848 & 1.923 & Hexatriacontane & 506 & $\mathrm{C}_{36} \mathrm{H}_{74}$ & No activity found \\
\hline 9. & 27.178 & 5.412 & Heptacosane & 380 & C27H56 & No activity found \\
\hline 10. & 27.744 & 6.549 & $\begin{array}{l}\text { 2h-1-Benzopyran-6- } \\
\text { O1, 3,4-Dihydro- } \\
\text { 2,5,7,8-Tetramethyl- } \\
\text { 2-(4,8,12-Trimethy }\end{array}$ & 472 & $\mathrm{C}_{31} \mathrm{H}_{52} \mathrm{O}_{3}$ & Antioxidant, Antimicrobial \\
\hline 11. & 28.784 & 2.095 & Di-N-Decylsulfone & 346 & $\mathrm{C}_{20} \mathrm{H}_{42} \mathrm{O}_{2} \mathrm{~S}$ & No activity found \\
\hline 12. & 31.37 & 2.963 & $\begin{array}{l}\text { 1,2- } \\
\text { Bis(Trimethylsilyl)Be } \\
\text { nzene }\end{array}$ & 222 & $\mathrm{C}_{12} \mathrm{H}_{22} \mathrm{~S}_{12}$ & No activity found \\
\hline
\end{tabular}

Figure2. GC-MS analysis of ethanolic leaf extract of Catharanthus roseus

\section{Qualitative Report}

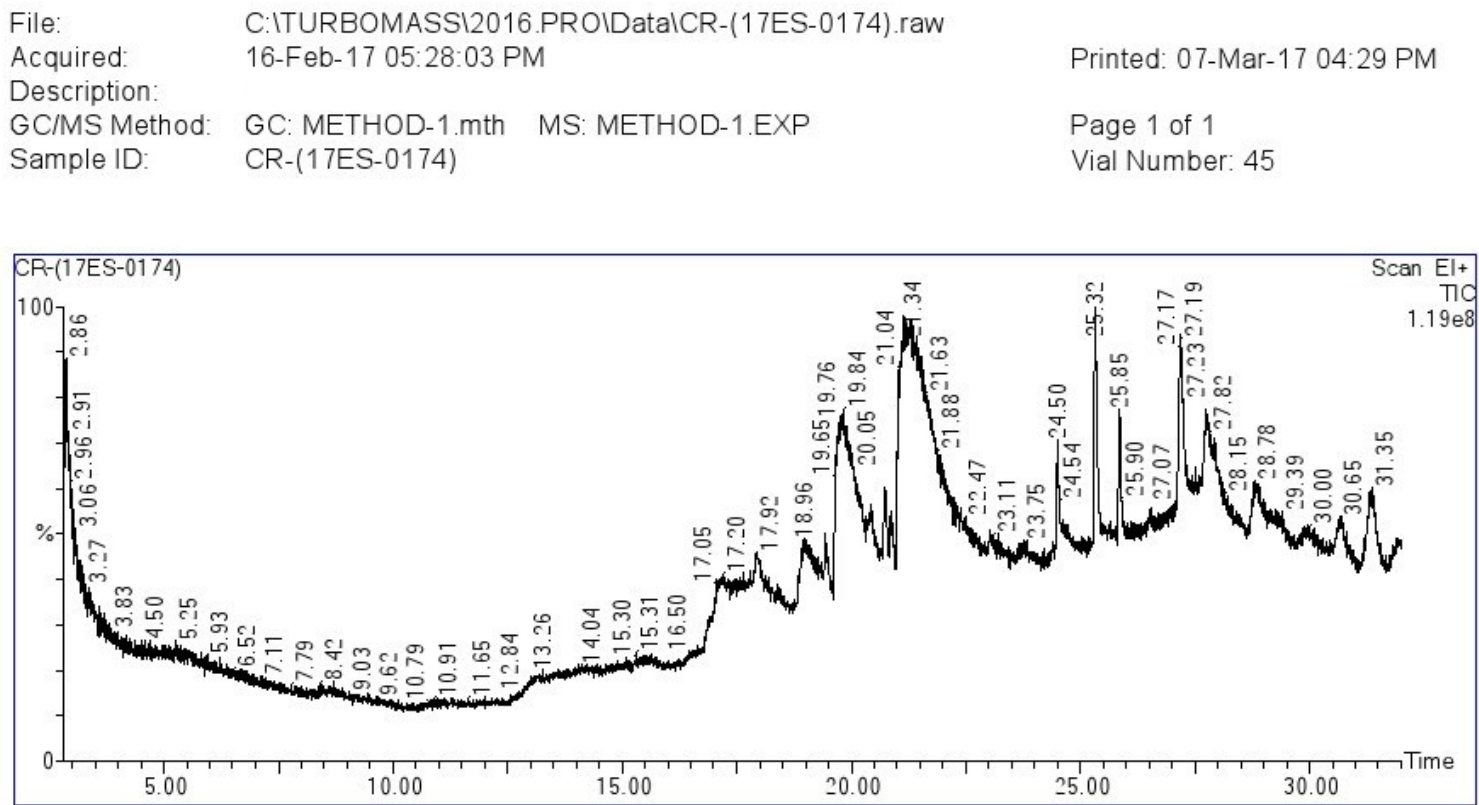




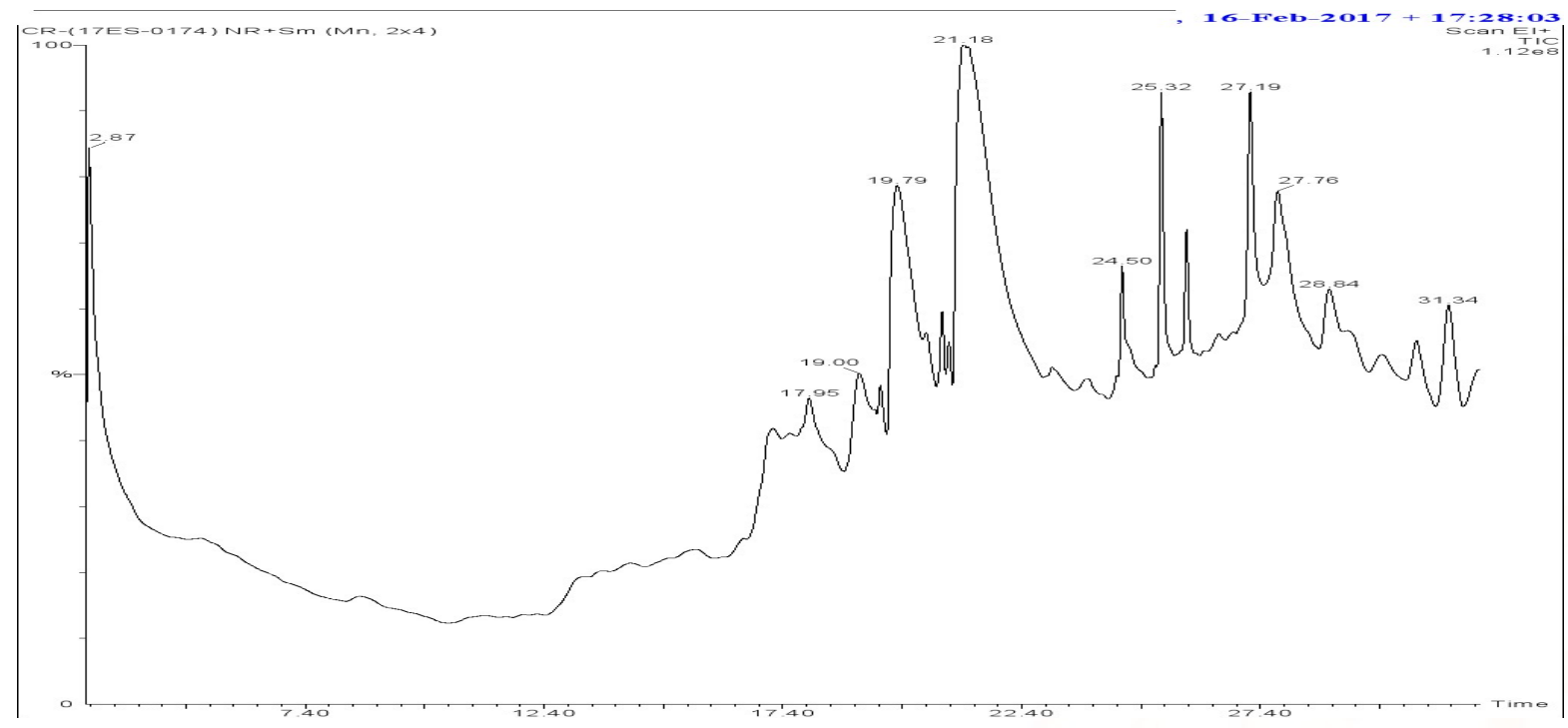

\section{REFERENCES}

1. Home page on the internet, World Health Organization, available from url http:// www.who.int / medicines/ areas / traditional/ definitions /en/.

2. Aneesh TP, Mohamed Hisham, Sonal Sekhar M, Manjusree Madhu Deepa TV. International Market Scenario of Traditional Indian Herbal Drugs. Int. J. Green Pharm. 2009; 3 suppl 3: 184190.

3. Mayuri Thanwar, Dhananjay Dwivedi and Anil Kumar G. 2017 GC-MS Study of Methanolic Extract of Leaves of Catharanthus roseus Journal of Chemical and Pharmaceutical Research, 2017, 9(4):375-377.

4. G.M. Krishnaiah, Prashanth G.K. Phytochemical Studies and GC-MS Analysis of the Leaf Extracts of Melia Azedarach Linn International Journal of Advancement in Engineering Technology Management \& Applied Science, 2014, Volume 1, Issue 6.

5. S. Patharajan and BalaAbirami 2014. Antioxidant activity and Phytochemical Analysis of Fractionated leaf extracts of Catharanthus roseus: International journal of Pharmacognosy, Vol. 1(2): 138-143.

6. Gajalakshmi S, Vijayalakshmi S and Devi Rajeswariv 2013 Pharmacological activities of Cathranthus roseus: A Perspective review International Journal of Pharma and Bio Science, (p) 431-439.
7. RNS Yadav and Munin Agarwala. Phytochemical analysis of some medicinal plants Journal of Phytology 2011, 3(12): 10-14.

8. Sofowra, A. 1993. Medicinal Plants and traditional Medicine in Africa. Spectrum Books Ltd., Ibadan, Nigeria, pp. 191-289.

9. Trease, G.E., Evans, W.C. 1989. Pharmacognosy, 11th edn., Bailliere Tindall, London, pp. 45-50.

10. Harborne, J.B. 1973. Phytochemicals Methods. Chapman and Hall Ltd., London, pp. 49-188.

11. Senthamarai Selvi. V and Anusha Basker. Phytochemical Analysis and GC-MS profiling in the leaves of Sauropus Androgynus (1) MERR International Journal of Drug Development \& Research January-March 2012 | Vol. 4 | Issue 1.

12. Rukshana MS, Doss A and Kumari Pushpa Rani TP. Phytochemical Screening and GC-MS Analysis of Leaf Extract of Pergularia daemia (Forssk) Chiov, Asian Journal of Plant Science and Research, 2017, 7(1):9-15

13. Arumugam Kathirvel, Venugopal Sujatha. Phytochemical studies, antioxidant activities and identification of active compounds using GC-MS of Dryopteris cochleata leavesArabian Journal of Chemistry, 2016 9, S1435-S1442.

14. Robson Miranda da Gama, Marcelo Guimarães, Luiz Carlos de Abreu, José Armando-Junior. Phytochemical screening and antioxidant activity of ethanol extract of Tithonia diversifolia (Hemsl) A. Gray dry flowers, Asian Pac J Trop Biomed 2014; 4(9): 740-742.

15. Elizabeth Thomas, Aneesh T. P, Della Grace Thomas, R. Anandan. Gc-Ms Analysis Of 
Phytochemical Compounds Present In The Rhizomes Of Nervilia aragoana Gaud, Asian Journal of Pharmaceutical and Clinical Research, 2013, Vol. 6, Suppl. 3.

16. A. Malar Retna and P. Ethalsha. Phytochemical Tests, Antioxidant Potential and TLC Analysis of Ipomoea Pes Caprae and Catharanthus Roseus. International Journal of Natural Products Research, 2014, 4(2): 58-64.

17. S. Chandra Mohan, T. Anand, G. S. Priyadharshini, V. Balamurugan. GC-MS Analysis of Phytochemicals and Hypoglycemic Effect of Catharanthus roseus in Alloxan-Induced Diabetic Rats, Int. J. Pharm. Sci. Rev. Res., 31(1), March - April 2015; Article No. 25, Pages: 123128.

18. Purabi Roy, Sarika Amdekar, Avnish Kumar and Vinod Singh. Preliminary study of the antioxidant properties of flowers and roots of Pyrostegia venusta (Ker Gawl) Miers. BMC Complementary and Alternative Medicine 2011, 11:69.

19. Manigandan M, Kolanjinathan K. Qualitative Phytochemical Screening and Antioxidant Activity of Elytraria Acaulis Lindau (Acanthaceae). Asian Journal of Pharmaceutical and Clinical Research, 2016, Vol 9, Suppl. 3.
20. Jananie, R.K., Priya, K., Vijayalakshmi, K., 2011. Determination of bioactive components of cynodon dactylon by GC-MS analysis. Newyork Sci. J. 4 (4), 16-19.

21. Dhivya Sm, Kalaichelvi K. Phytochemical Studies and Gas Chromatography-Mass Spectrometry Analysis of Sarcostemma Brevistigma, Wight \& Arn. Asian Journal of Pharmaceutical and Clinical Research, 2017, Vol 10, Issue 3.

22. Janakiraman N, Johnson M, Sathish SS. GC-MS analysis of bioactive constituents of Peristrophe bicalyculata (Rets.) Nees. (Acanthaceae). Asian Pac J Trop Biomed 2012; 46-9.

23. Karuppasamy B, Antony N, Veerabahu RM. GCMS analysis of Polycarpaea corymbosa (L.) Lam. whole plant. Asian Pac J Trop Biomed 2012; 2(3):1289-92.

24. Mustapha N. Abubakar and Runner R. T. Majinda. GC-MS Analysis and Preliminary Antimicrobial Activity of Albizia adianthifolia (Schumach) and Pterocarpus angolensis (DC) Medicines 2016, 3, 3; doi: 10.3390/medicines 3010003 . 